\title{
Sosyal Bilgiler Öğretmen Adaylarının Akran Değerlendirmesine İlişkin Görüşleri
}

\author{
Mehmet AKPINAR ${ }^{1}$, Sevcan KRANDA² \\ ${ }^{1}$ Yrd. Doç. Dr., KTU, Fatih Eğitim Fakültesi Sosyal Bilimler ve Türkese Eğitimi Bölümü, makpinar66@yahoo.com \\ ${ }^{2}$ Yüksek Lisans Ögrrencisi, KTU Eğitim Bilimleri Enstitüsü, sevcan.kranda.sk@gmail.com
}

Geliş Tarihi/Received: 23.6.2016

Kabul Tarihi/Accepted: 14.12.2016

e-Yayım/e-Printed: 3.1.2017

DOI: http://dx.doi.org/10.14582/DUZGEF.768

ÖZ

Bu çalısma, sosyal bilgiler öğretmen adaylarının alternatif ölçme değerlendirme yöntemlerinden olan akran değerlendirmesine yönelik görüşlerinin incelenmesi amacıyla yapılmıştır. Araştırmaya Karadeniz Teknik Üniversitesi Sosyal Bilimler ve Türkçe Eğitimi Bölümü Sosyal Bilgiler Eğitimi Anabilimdalı dördüncü sınıfında öğrenim gören 47 öğretmen adayı katılmıştır. Araştırmaya katılan öğretmen adaylarından 24’ü Özel Öğretim Yöntemleri dersinde akran değerlendirmesi yaptıklarını belirtirken, 23 öğretmen adayı ise Özel Öğretim Yöntemleri dersinde sadece teorik olarak akran değerlendirmesi hakkında bilgi edindiklerini, uygulama yapmadıklarını ifade etmiştir. Öğretmen adaylarının akran değerlendirmeye ilişkin görüşleri açı uçlu anket soruları ile alınmış ve anketlerden elde edilen veriler içerik analizi yöntemi kullanılarak yorumlanmıştır. Öğretmen adaylarının çoğunun akran değerlendirmesine ilişkin olumlu görüşlere sahip olduğu ortaya çıkmıştır. Öğretmen adayları, akran değerlendirmenin, kendilerinin başarılı ve zayıf yönlerine ilişkin farkındalığı artırdığını; arkadaşlarının başarılı ve zayıf yönlerinden öğrenmelerin gerçekleşmesini desteklediğini; eleştirilere karşı açık olmayı geliştirdiğini; değerlendirme becerisi kazandırdığını ve eleştirel düşünmeyi geliştirdiğini düşünmektedirler. Bununla birlikte akran değerlendirmesi ile ilgili olumsuz olarak, değerlendirme yaparken objektif olunmadığı görüşü üzerinde durdukları görülmüştür. Bulgular, akran değerlendirmesi yapan grubun yapmayan gruba göre akran değerlendirmesine ilişkin daha olumlu görüşlere sahip olduğunu ortaya çıarmıştır. Bununla birlikte iki grubun da en yüksek frekansa sahip kategorilerinin aynı olduğu görülmüştür. Araştırmada elde edilen sonuçlar, akran değerlendirmenin sürecin yapılandırılmasında etkili bir yöntem olduğunu göstermekle birlikte uygulamada sıkıntıların yaşandığını ortaya koymuştur. Bu sonuçlar doğrultusunda öğrencilerin akranlarını nasıl değerlendirecekleri konusunda bilgilendirilmesi ve akran değerlendirmede yer alacak ölçütlerin öğrenci görüsslerinin alınarak belirlenmesi şeklinde önerilerde bulunulmuştur.

Anahtar Kelimeler: Akran değerlendirmesi, öğrenci görüşleri, akran eğitimi.

\section{View of Social Sciences Student Teachers on Peer Assessment}

\begin{abstract}
The main purpose of this research is to investigate the opinions of social studies teacher candidates about peer review which is one of the alternative assessment and evaluation method. 47 senior teacher candidates who studied in the Karadeniz Technical University, Social Science and Department of Turkish Education, Social Studies Education Department participated the study. 24 teacher candidates out of 47 indicated that they have done peer review in the special teaching methods course, on the other hand, 23 of them stated that they were informed theoretically about the peer review but have not done. Opinions of the teacher candidates were taken with open ended survey questions and the data gathered from surveys were interpreted by using content analysis. It is emerged that most of the teacher candidates gave positive opinions about peer review. Teacher candidates think that peer review increases the awareness about strengths and weaknesses of themselves; supports the learning from their friends' strengths and weaknesses; enhances to be open to criticism; upskills of evaluation and develops critical thinking. However, as a negative side of peer review, it is seen that teacher candidates discourses on being nonobjective while doing review. Findings suggested that teacher candidates who have done peer review have more positive opinions about peer review than the teacher candidates who have not done peer review. In addition to this, category that have the highest frequencies for both group is same. Results reveal that, although peer review is an effective method for construction of the process, performing peer review have some difficulty. In accordance with these results, it is suggested that informed educating the teacher candidates about how to review their peers and determining the criteries in peer assessment by asking student's opinions.
\end{abstract}

Keywords: Peer assessment, Students views, Peer learning 


\section{GİRİ̧̧}

Değişen ve gelişen toplumlarda bilim ve teknolojinin taleplerini karşılayan niteliklere sahip insanların yetiştirilmesi, eğitimin temel işlevlerindendir (Toptaş, 2011). Toplumların gelişimine paralel olarak eğitimden beklentiler de değişmeye başlamıştır. Değişen ve gelişen toplumsal ihtiyaçlara cevap verebilmek için dinamik bir öğretim programına ihtiyaç vardır. Bundan dolayı öğretim programları sürekli geliştirilmekte ve çağın ihtiyaçlarına cevap verecek nitelikte yenilenmektedir. Dünyada olduğu gibi ülkemizde de öğretim programları toplumsal ihtiyaçlara göre ele alınmış olup yeni öğretim yaklaşımlarıyla yeniden şekillendirilmiştir. Bu yeni yaklaşımların ortaya çıkmasında bilginin ürün olmaktan çıkıp süreç haline gelmesi etkili olmuştur (Çelikkaya, Karakuş \& Demirbaş, 2010). Yenilenen bu programlarda öğrencinin bilgiyi yapılandırdığı kabul edilmektedir. Yeni öğretim yaklaşımlarıyla şekillenen bu öğretim programlarılyla derslerin içeriğinde, öğretim yöntemlerinde, kullanılan araç ve gereçlerle ölçme ve değerlendirme yöntemlerinde de değişiklikler yaşanmıştır (Gelbal \& Kelecioğlu, 2007).

Geleneksel ölçme-değerlendirme uygulamalarında öğrenci başarısının değerlendirilmesi genellikle ürün odaklı olmakta ve daha çok seçmeli ve kısa cevaplı testlerle, yazılı ve sözlü yoklamalar kullanılmaktadır (Gelbal \& Kelecioğlu, 2007, s. 136). Ancak söz konusu ölçme araçları ile yapılan değerlendirmeler öğrenme sürecinde meydana gelen istenilen davranış değişikliklerinin tespitinde ve kazandırılmasında yetersiz kalmaktadır. Çünkü her öğrencinin bilgiyi yapılandırma süreci farklı olmaktadır. Dolayısıyla sadece sonuca göre bir değerlendirme yapmak eksik değerlendirmelere yol açacaktır. Bu bağlamda geleneksel ölçme-değerlendirme yaklaşımlarının yanı sıra süreci ölçen alternatif ölçme ve değerlendirme yaklaşımları geliştirilmiştir (Çelikkaya, Karakuş \& Demirbaş, 2010). Yeni bir anlayışla hazırlanan öğretim programlarının 2005'ten beri uygulanmasıyla birlikte de öğrenciyi merkeze alan bu alternatif yaklaşımlar kullanılmaya başlanmıştır. $\mathrm{Bu}$ anlayış sonucunda hem öğrenme-öğretme etkinliklerinin hem de ölçme-değerlendirme etkinliklerinin otantik bir yapıda olması gerekliliği ortaya çıkmıştır. Yapılandırmacı anlayış çerçevesinde ortaya konulan bu alternatif ölçme değerlendirme yaklaşımlarıyla öğrencilerin bilişsel, devinimsel, duyuşsal alanlardaki bilgi ve becerilerini farklı yollardan ortaya çıkarmak amaçlanmaktadır. Bireyin sahip olduğu bilişsel, duyuşsal ve devinimsel alandaki kapasitesi ve bu kapasiteyi göstermesi onun performansını ortaya koymaktadır (Adanalı \& Doğanay, 2010). Bu durum öğrenci merkezli etkinliklerle desteklenen bir süreci işaret etmektedir.

Geleneksel ölçme-değerlendirme yaklaşımları, öğrenme etkinlikleri sonunda öğrencilerin hangi davranışları, ne düzeyde kazandıklarını belirleme amacı taşır. Alternatif ölçme-değerlendirme yaklaşımlarında ise öğrencilerin öğrenme ortamında desteklenmesi ve yeteneklerinin ortaya çıkarılması hedeflenmektedir (Çepni, 2007). Öğrenme etkinlik ve uygulamalarının değerlendirilmesinde hem geleneksel ölçme-değerlendirme yaklaşımlarının hem de bireysel ve grup görüşmeleri, öğrenci günlükleri, Öz değerlendirme, akran değerlendirme, portfolyo, performans değerlendirme ve proje gibi öğrencilerin performanslarının süreç içerinde değerlendirilmesini sağlayan alternatif ölçme-değerlendirme yaklaşımlarının kullanılması önerilmektedir (Baki, 2008). Bu yaklaşımlardan en önemli olanlardan biri de akran değerlendirmesidir. Öğrencileri değerlendirme sürecinin içerisine alan akran değerlendirme, öğretim 
süreci içerisinde öğrencinin hazırladığı araştırma, ödev ve proje gibi çalışmaların arkadaşları tarafindan değerlendirilmesidir (Alıc1, 2008). Öğrenciler akran değerlendirmesi sayesinde kendilerini kritik etme imkanı bulmakta ve arkadaşlarının çalışmalarını kendi çalışmaları ile kıyaslayarak alternatif bir bakış açısı kazanmaktadırlar. Bunun yanı sıra, öğrencilerin arkadaşları tarafindan değerlendirilmesi ve geribildirim alması öğrencinin öğrenme sürecine de olumlu katkılarda bulunmaktadır (Aldağ \& Gürpınar, 2007). Akran değerlendirmesi hem ürünün hem de sürecin değerlendirildiği durumlarda kullanılabilmektedir. Akran değerlendirme öğrencilerin eleştirel düşünme ve yaratıcllık becerilerini geliştiren önemli bir araçtır. Birçok öğrenci birbirlerinin çalışmalarını değerlendirirken kendi öğrenmelerini geliştirdiğini bildirmiştir (Chong, Goff \& Dej, 2012). Akran değerlendirmesinde kullanılan ölçütler ve değerlendirme sonunda akranların birbirlerine sundukları dönütler önemli bir role sahiptir. Ayrıca ölçütlerin öğrenciler tarafindan iyi anlaşılıp benimsenmesi akran değerlendirme sürecinin etkili olmasında son derece önemli görülen bir noktadır (Koç, 2011). Bu ölçme değerlendirme yaklaşımlarının kullanılabilmesi için öğretmenlerin yeni öğretim programının getirmiş olduğu alternatif ölçme tekniklerini derslerinde kullanabilmelerini sağlayacak bilgi, beceri ve deneyime sahip olması gerekmektedir (Çoruhlu, Nas \& Çepni, 2009). Literatüre bakıldığında ögretmenlerin alternatif ölçme-değerlendirme uygulamaları hakkında yeterince bilgi sahibi olmadıkları ve bu uygulamaları yeterince içselleştiremedikleri görülmektedir (Güven, 2008; Çoruhlu, Nas \& Çepni, 2009). Uzun yıllar geleneksel yaklaşıma göre ölçme değerlendirme yapan öğretmenler yeni yaklaşıma adapte olma konusunda sorunlar yaşamaktadırlar (Akbaş \& Gençtürk, 2013). Bu durumu Çoruhlu, Nas ve Çepni (2009) araştırmalarında, öğretmenlerin geleneksel ölçme değerlendirme tekniklerini derslerinde kullanmaktan vazgeçmedikleri, bilgi ve deneyim eksikliğinden kaynaklanan sorunlardan dolayı yeniliklere uyum sağlamada zorlandıkları ve kullanmış oldukları geleneksel ölçme değerlendirme tekniklerini 2004 öğretim programına adapte etmeye çalışııkları şeklinde ortaya koymuşlardır. Bunun sonucu olarak alternatif ölçme değerlendirme tekniklerini öğretmenlerin daha çok kendi kabullerine paralel olarak kullandığı meydana çıkmaktadır.

Literatür incelemesi sonucunda akran değerlendirmesi tekniğinin kullanımı konusundaki öğretmen adaylarının görüşleri, yeterliliği ve kullanımı hakkında sınırlı sayıda çalışma yapıldığı görülmektedir. Koç (2011)'un sınıf öğretmeni adaylarının akran değerlendirmesiyle ilgili görüsslerini aldığ1 çalışması, akran değerlendirmenin öğretmenlik yeterliklerini geliştirdiğini ve öğretmenlik uygulaması sürecinin yapılandırılmasında etkili bir yöntem olduğunu göstermektedir. Tıp eğitiminde Özan ve Yurdabakan (2008) tarafindan yapılan bir çalşmada öz ve akran değerlendirme uygulamalarının tıp fakültesi öğrencilerinin temel iletişim becerileri başarısı üzerindeki etkileri incelenmiştir. Öntest-sontest kontrol gruplu deneme modeli kullanılan araştırmanın sonunda, öz ve akran değerlendirmenin kullanıldığı deney grubundaki öğrencilerin başarılarındaki artışın, kontrol grubu öğrencilerinin başarılarındaki artıştan anlamlı olarak daha yüksek olduğu bulunmuştur. Öğrencilerin büyük çoğunluğunun öz ve akran değerlendirme uygulamalarına olumlu yaklaştıkları, bu değerlendirme uygulamalarının öğrencilerin eğitime katılımlarını ve eğitimden kazanımlarını arttırdığını vurguladıkları görülmüştür. Temizkan (2009)'ın yaptığı çalışmada, Türkçe Öğretmenliği 3. sınıf öğrencilerinin konuşma becerilerinin geliştirilmesinde akran değerlendirmenin etkisini tespit etmek amaçlanmıştır. Elde edilen sonuçlara göre, hazırlıklı konuşma uygulaması yapan öğrencilerin akran değerlendirme puanlarına ilişkin ön test ve son test sonuçları arasında son test lehine 
anlamlı bir ilişki ortaya çıkmıştır. Akran değerlendirmenin konuşma becerilerinin geliştirilmesi açısından etkili sonucuna varılmıştır. Yurdabakan ve Cihanoğlu (2009) tarafından yapılan bir çalısmada, işbirlikli öğrenme ortamlarında kullanılan öz ve akran değerlendirmenin 10. Sınıf öğrencilerinin akademik başarıları, derse yönelik tutumları ve strateji kullanım düzeyleri üzerindeki etkileri incelenmiş, öz ve akran değerlendirmenin işbirlikli öğrenme ortamlarında öğrencilerin İngilizce başarıları, derse dönük tutumlar ve duyuşsal boyut hariç strateji kullanımları üzerinde etkili olduğu saptanmıştır. Bayat (2010)'ın çalışmasında elde ettiği bulgulara göre İngilizce yazılı anlatım derslerinde uygulanan akran değerlendirme ve öz değerlendirme uygulamalarına yönelik öğrenci görüşleri öğrenmenin pekiştirilmesi, kendi öğrenmesini değerlendirme, öz güvenin pekiştirilmesi bakımından olumludur. Çetinkaya ve Hamzadayı (2011)'nın yazılı anlatımı düzenlemedeki işlevselliği açısından akran değerlendirmesinin sorgulandığı çalışmalarında, dönütlere ilişkin çözümlemelerden elde edilen bulgular ve öğrencilerin algıları, dönüt sağlama konusunda verilecek bir eğitimle birlikte yazılı anlatımı düzenlemede akran değerlendirmesinin verimli bir öğretim etkinliği olarak kullanılabileceği sonucunu ortaya koymaktadır. Liu ve Carless (2006)'ın yaptıkları çalışmada, değerlendirme süreçlerine ilişkin akran geribildirimi üzerinde durulmakta ve öğrencinin öğrenme potansiyelinin arttırılmasında akran geri bildiriminin önemi incelenip tartışılmaktadır. Yukarıda sözü edilen bu çalışsmalar, alternatif ölçme değerlendirme tekniklerinden olan akran değerlendirmesinin etkililiğinde grup değişkenlerinin önemli bir yerinin olduğunu göstermektedir. Bu durum da, akran değerlendirmenin uygulanmasının ve etkililiğinin her bir öğretim kademesi için sorgulanmasını gerektirmektedir. Geleceğin öğretmenleri olacak olan öğretmen adaylarının akran değerlendirmesine ilişkin becerileri kazanarak bu değerlendirme yöntemine olumlu yaklaşmaları, onların gelecekte akran değerlendirme yöntemini kullanması açısından önemli görülmektedir. Ayrıca, akranlarının çalısmalarını değerlendirebilmek öğretmen adaylarının profesyonel gelişimi için önemli bir koşuldur (Sluijsmans \& Prins, 2006). Bu amaçla; araştırmada öğretmen adaylarının akran değerlendirmesi hakkındaki görüşleri ortaya konmak istenmiştir. Sosyal bilgiler öğretmen adaylarının bu konudaki görüşlerini ortaya koyan yeterli sayıda çalışmaya rastlanmamış olması da bu türden tespitlerin yapılarak bu konudaki eksikliğin ortaya konması açısından önemlidir. Bu bağlamda çalışmada sosyal bilgiler öğretmen adaylarının akran değerlendirmesine ilişkin görüşlerinin incelenmesine yer verilmiştir.

\subsection{Araştırmanın Amacı}

$\mathrm{Bu}$ araştırmada, sosyal bilgiler öğretmen adaylarının alternatif ölçme değerlendirme yöntemlerinden akran değerlendirmesine ilişkin görüşlerinin incelenmesi amaçlanmıştır. Bu amaçla Özel Öğretim Yöntemleri dersinde akran değerlendirmesi yapan ve yapmayan öğretmen adaylarının görüşleri alınmıştır.

\subsection{Araştırmanın Gerekçesi}

Ülkemiz eğitim sistemi ve konu ile ilgili yapılan çalışmalar öğrenci merkezli model ve yöntemlerle derslerin işlenmesi gerektiği ile ilgili vurgular yapmaktadır. Ancak, öğretmenlerin sadece bu model ve yöntemler hakkında bilgi sahibi olmaları değil, aynı zamanda bunları uygulama güçlerine de sahip olmaları gerekmektedir. Bunun için de öğretmen yetiştiren kurumlarda öğretmen adaylarına bu tür model ve yöntemlerin tanıtılmasının ve uygulatılmasının sağlanması gerekmektedir. Bu amaçla, bu model ve yöntemlere ilişkin öğretmen adaylarının görüşlerini içeren çalışmalar yapmak gerekir. (Mirzeoğlu \& Özcan, 2015). Çünkü eğitim sisteminin uygulayıcıları öğretmenlerdir. Yarının öğretmeni olacak olan öğretmen 
adaylarının akran değerlendirmesine ilişkin görüşlerini belirtmeleri, onların mesleki yaşamında profesyonel olarak gelişimlerine yardımcı olacağı düşünülmektedir.

Yapılan literatür taraması sonucunda, sosyal bilgiler öğretmen adaylarının akran değerlendirmesine ilişkin görüşlerinin yer aldığı çalışmaların sınırlı olduğu görülmüştür. Öğretmen adaylarının akran değerlendirmesine ilişkin görüsslerinin belirlenerek bu değerlendirme yönteminin ne gibi yararları olduğu, öğretmen adaylarının bu süreçte ne tür olumsuzluklarla karşılaş̧ı̆̆ı ortaya koyulmaya çalışılmıştır. Yapılan bu çalışmanın diğer alanlardaki araştırmacıların yapacakları akran değerlendirmesi çalışmalarına sşık tutacağı düşünülmektedir. Tüm bu amaçlar göz önünde bulundurulduğunda aşağıdaki sorulara yanıt aranmaya çalışılmıştır:

1) Sosyal bilgiler öğretmen adaylarının akran değerlendirmesine ilişkin görüşleri nelerdir?

2) Sosyal bilgiler öğretmen adayları akran değerlendirmesinde puanlama yaparken nelere dikkat etmektedirler?

3) Sosyal bilgiler öğretmen adaylarının akran değerlendirmesinin olumlu yönlerine ilişkin görüşleri nelerdir?

4) Sosyal bilgiler öğretmen adaylarının akran değerlendirmesinin olumsuz yönlerine ilişkin görüşleri nelerdir?

5) Sosyal bilgiler öğretmen adaylarının akranları tarafindan değerlendirilme konusundaki görüşleri nelerdir?

6) Sosyal bilgiler öğretmen adaylarının akran değerlendirmesine ilişkin önerileri nelerdir?

\section{YÖNTEM}

$\mathrm{Bu}$ çalışma nitel araştırma yaklaşımı çerçevesinde tasarlanmış ve yürütülmüştür. Çalışmada sosyal bilimlerde giderek yaygınlaşan nitel araştırma yaklaşımının yöntemlerinden biri olan "özel durum çalışması” yöntemi kullanılmıştır. Özel durum yönteminin en belirgin özelliği, güncel bir olgu, olay, durum, birey ve gruplar üzerinde odaklanıp derinlemesine inceleme yapmaya çalışmasıdır (Yıldırım \& Şimşek, 2011). Bir diğer ifadeyle araştırmacının konuyla ilgili önyargılara sahip olmadan bireyler üzerinden konunun etraflıca incelenmeye çalışılmasıdır (Ekiz, 2009).

\section{1. Çalışma Grubu}

Çalışma grubu, 2015-2016 eğitim-öğretim yll güz döneminde Karadeniz Teknik Üniversitesi, Fatih Eğitim Fakültesi, Sosyal Bilimler ve Türkçe Eğitimi Bölümü Sosyal Bilgiler Öğretmenliği’ne kayıtlı olan dördüncü sınıf öğrencileridir. Çalışma grubu toplam 47 öğrenciden oluşmakta bunlardan 25’i kız, 22’si erkek öğrencidir. Bu öğrencilerin 24’ü Özel Öğretim Yöntemleri dersinde akran değerlendirmesi yapmış, 23’ü ise akran değerlendirmesini kullanmamıstır.

\subsection{Veri Toplama Araçlar1}

Araştırmada, sosyal bilgiler öğretmen adaylarının akran değerlendirmesi hakkındaki görüşleri tespit edilmek istendiğinden ve çalşmaya katılan birey sayısının da fazla olması nedeniyle veri toplama aracı olarak açık uçlu anket uygulanması tercih edilmiştir. Açık uçlu anket "Soruya cevap veren bireyin soruda boş bırakılan yere, bir kelime, bir cümle yazması veya kendi fikrini beyan etmesidir” (Çepni, 2009). Bu 
bağlamda öğretmen adaylarının akran değerlendirmesine ilişkin görüşlerini belirlemek amacıyla ilgili literatür incelenmiş ve sosyal bilgiler eğitimi alanında uzman bir kişinin görüşü alınarak açık uçlu 6 sorudan oluşan anket oluşturulmuştur.

\subsection{Verilerin Analizi}

Araştırmadan elde edilen veriler "içerik analizi” yöntemi kullanılarak yorumlanmıştır. Analiz sürecinde her bir öğretmen adayının ifade ettiği temel düşünceler ortaya çıkarılmış ve daha sonra bu düşüncelerden ortak olanlar ve araştırma sorusuna cevap teşkil edenlerin frekansları belirlenmiş ve kategoriler halinde sunulmuştur. Ortaya çıkan temel düşünceler benzer kategoriler alında toplanıp daha sonra analiz edilmiştir (Büyüköztürk, 2001; Yıldırım \& Şimşek, 2011). Bu yolla analizler karşılaştırllarak var olan durum şekiller halinde sunularak ifade edilmeye çalışılmıştır. Elde edilen veriler öğretmen adaylarının konuşmalarından doğrudan alıntılar yapılarak desteklenmiştir.

\section{BULGULAR ve TARTIŞMA}

$\mathrm{Bu}$ bölümde, araştırma çerçevesinde yapılan anketlerde öğretmen adaylarının, kendilerine yöneltilen açık uçlu sorulara verdikleri cevaplardan elde edilen bulgular yer almaktadır. Sorulara verilen yanıtlardan oluşturulan altı ana başlık altındaki kategoriler aşağıdaki tablolarda sunulmuştur.

Öğretmen adaylarına ön anket sorusu olarak, Özel Öğretim Yöntemleri dersinde akran değerlendirmesi yapıp yapmama durumlarını tespit etmek amacıyla bir soru yöneltilmiştir. Bunun sonucunda, 47 öğretmen adayından 24 tanesinin Özel Öğretim Yöntemleri dersinde akran değerlendirmesi yaptığ1 görülmüştür. 23 tane öğretmen adayının ise akran değerlendirmesi yapmadığı belirlenmiştir.

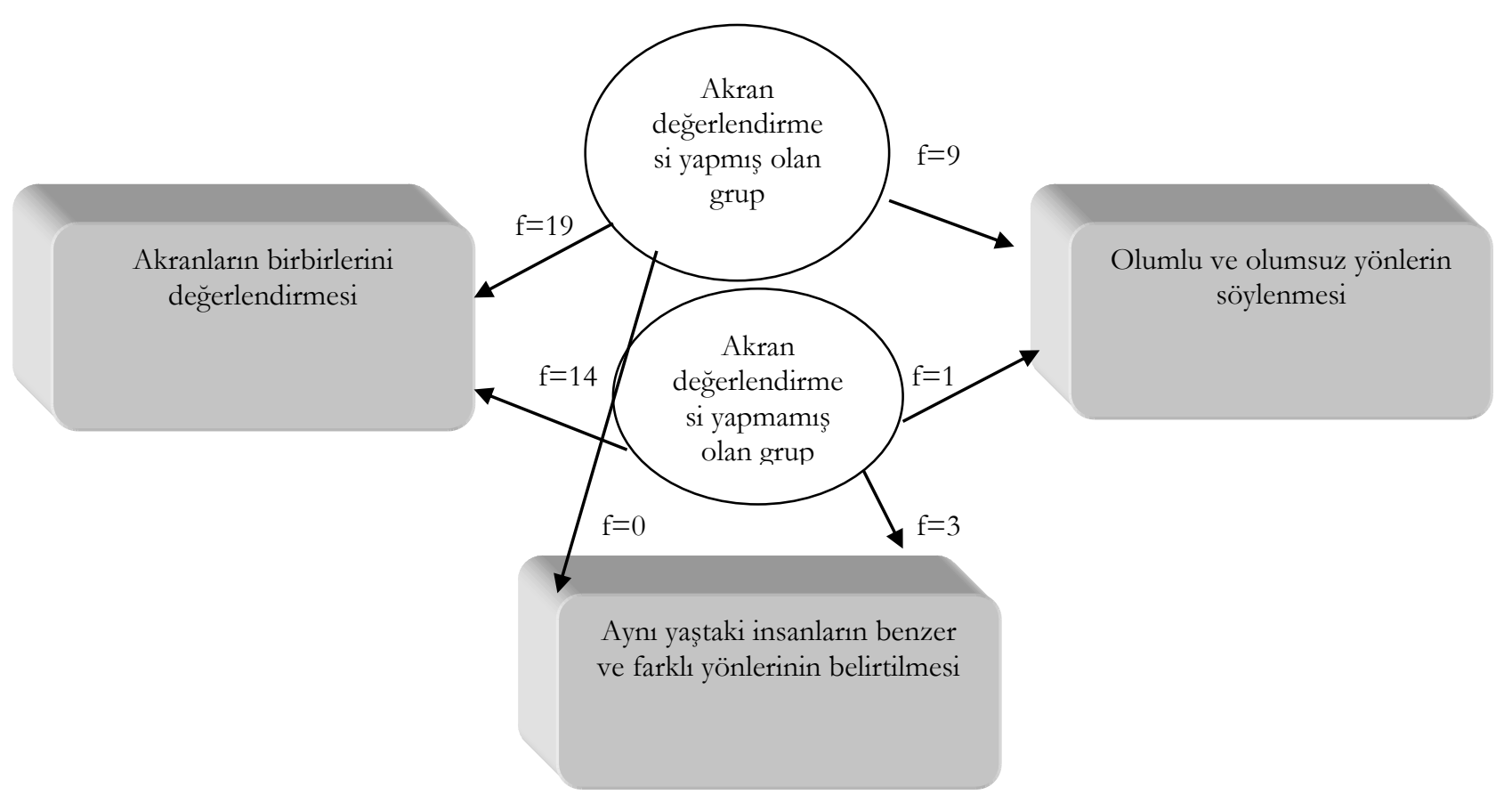

Şekil 1. Öğretmen adaylarının akran değerlendirmesinin ne olduğuna ilişkin görüşleri 
Şekil 1 incelendiğinde, öğretmen adaylarının akran değerlendirmesine ilişkin görüşlerine yönelik olarak 3 kategorinin ortaya çıttı̆ı ve bunlar arasından "akranların birbirlerini değerlendirmesi” kategorisinin ön planda olduğu görülmektedir. Öğretmen adaylarının ifade ettikleri görüşlerin 33’ünün akranlarının birbirini değerlendirmesi, 10’unun olumlu ve olumsuz yönlerin söylenmesi, 3’ünün aynı yaştaki insanların benzer ve farklı yönlerinin değerlendirilmesi ile ilgili olduğu ortaya çıkmaktadır. Örneğin K2 kodlu ( $K=K a d ı n)$. öğretmen aday1 "akranların birbirlerini değerlendirmesi” kategorisine yönelik olarak yaş ve statü kavramlarından bahsetmiş ve akran değerlendirmesine ilişkin şunları söylemiştir: "Yaş ve statü olarak aym olan kişilerin birbirlerini değerlendirmesidir". Benzer şekilde K8 kodlu öğretmen adayı görüşünü "Kişinin beli konularda sahip olduğu bilgi ve becerileri kendi yas grubuna ait diğer bireylerin değerlendirmesi sonucu kissiye dönüt sağlamasıdır" şeklinde belirterek yaş grubuna dikkat çekmiştir. "Olumlu ve olumsuz yönlerin söylenmesi”" kategorisine yönelik olarak E3 kodlu (E=Erkek) öğretmen aday1 görüşünü, "Akranlarmızın olumlu ve olumsuz yönlerinin göstermis olduğu performansa bakılarak söylenmesı” şeklinde açıklamıştır. K1 kodlu öğretmen aday1 ise, "Kişinin, akrammn doğru ve yanlş̧ yönlerini bir konu ya da konular açısından tenkit etmesidir" şeklinde cevap vermiştir.

Anket yapılan öğretmen adaylarından 2'sinin görüşü ise, en düşük frenkansa ( $f=1)$ sahiptir. E47 kodlu öğretmen adayının bu soruya verdiği cevap "Başkalarmnn gözünden bakarak kendi bakkenda bilgi edinmek." şeklindedir. K36 kodlu öğretmen adayı da "ögrrenciler arası iletişim dï̈eyini belirler" şeklinde görüş bildirmiştir.

Yapılan anket sonucunda elde edilen bulgular, öğretmen adaylarının akran değerlendirmesinin ne olduğuna ilişkin bilgi sahibi olduklarını göstermektedir. Falchikov (2001), akran değerlendirmesinde öğrencilerin belli ölçütlere göre akranlarının performansını değerlendirdiklerini ve akranları tarafindan değerlendirildiklerini belirtmiştir. Çalışmamızdan elde edilen bulgulara göre de, öğrenciler akran değerlendirmesine ilişkin görüşlerini aynı yaş ve statüdeki bireylerin birbirini değerlendirmesi, akranların birbirlerinin performanslarını olumlu ve olumsuz yönden değerlendirmesi şeklinde ifade etmişlerdir. 


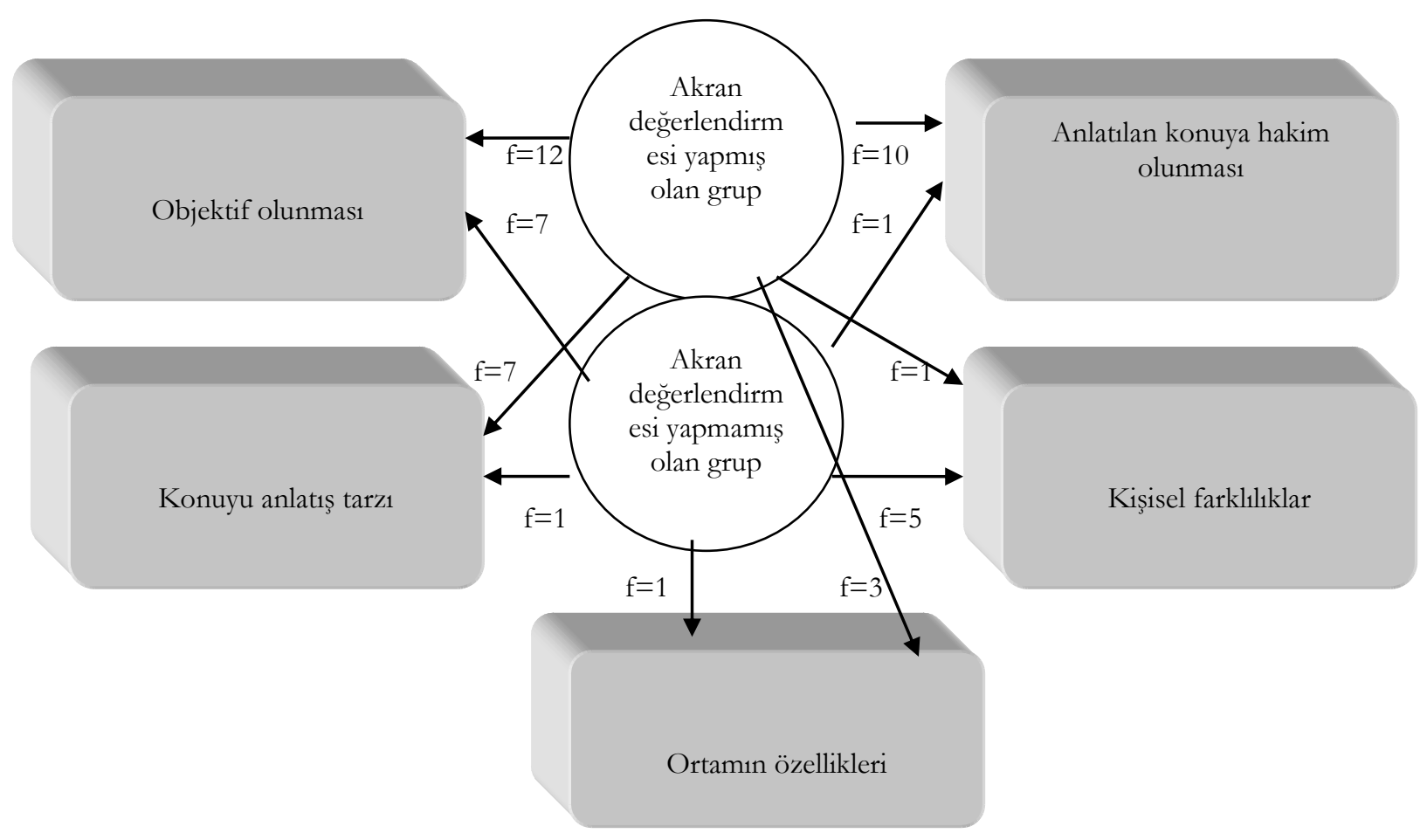

Şekil 2: Öğretmen adaylarının akran değerlendirmesinde puanlama yaparken dikkat ettikleri durumlara yönelik düşünceleri

Şekil 2'de de görüldüğ̈̈ gibi öğretmen adaylarının akran değerlendirmesinde puanlama yaparken dikkat edilmesi gereken durumlara yönelik olarak 4 kategori ortaya çıkmışır. Öğretmen adaylarının ifade ettikleri görüşlerin çoğu ( $\mathrm{f}=19)$ puanlama yaparken "objektif olunması" kategorisi ile ilgilidir. Bunu "anlatılan konuya hakim olunması", "anlatış tarzına" ve "kişisel farklılıklara dikkat edilmesi”, "ortamın özellikleri” gibi kategoriler izlemektedir. Örneğin, E14 kodlu öğretmen adayı “Akran değerlendirmesi yaparken değerlendirme ölçütünün ögrrenciler tarafindan bilinmesi ve değerlendirmede objektif davranlmast dikkat edilmesi gereken noktalardı" ifadesinde bulunmuştur.E3 kodlu öğretmen adayının görüşü ise "Akran değerlendirmesi yapıllrken, ölçme değerlendirme işlemi sirasında yapılma ibtimali olan bata türlerinin etkisinin en az̧a indirilmesine, kişiye karşı objektif olunmaya, yapılan uyarlarn meşru bir düzene oturtulup kişilerin öz. güven ve motivasyonlarmn kerrlmamasina ve

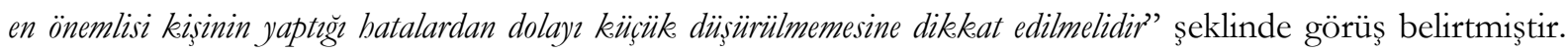
E20 kodlu öğretmen aday1 "Kişisel farklllkklara dikkat edilmesi gerekir" şeklinde açıklama yaparken, K45 kodlu öğretmen aday1 "Her ögrencinin farkh bir birey olduğu düş̈̈n̈̈lerek puanlama yapılmalıdır" şeklinde açıklama yapmıştır. E4 kodlu öğretmen adayının görüşü ise, "Puanlama yaparken arkadaşımıə̨n konuya hakim olmasına dikkat edilmesi gerekir" şeklindedir. Anlatış tarzı kategorisine K21 kodlu öğretmen adayının verdiği cevapta

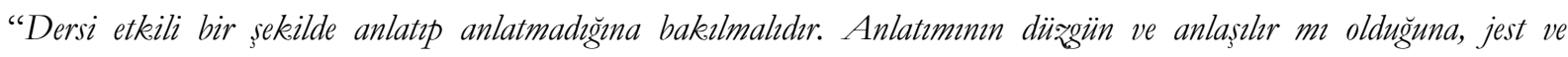
mimiklerini nasıl kullandrğına bakılmalddr” ifadesi yer almaktadır. "E42, K1, E10 ve K13 kodlu öğretmen adayları ise, içinde bulunulan ortamın özelliklerinin puanlama yaparken dikkate alınması gerektiğini belirtmiştir. K13 kodlu öğretmen adayının bu konudaki görüşü “Akran değerlendirmesi yaparken içinde bulunulan şartlarn göz önüne alması gerektiüini düsün̈̈yorum” şeklindeyken, K1 kodlu öğretmen adayını görüşü 
“O anın özellikleriyle eleştirmeye dikkat edilmeli” şeklindedir. $\mathrm{Bu}$ soruyu 3 kişi cevap vermeyerek boş birakmıştır.

Öğretmen adaylarının akran değerlendirmesinde puanlama yaparken en çok üzerinde durdukları nokta objektif olunması gerektiğidir. Ayrıca anlatılan konuya ve konuyu anlatış tarzına da öğretmen adaylarının puanlama yaparken dikkat ettikleri görülmektedir. Elde edilen bulgularda akran değerlendirmesi yapan grupla yapmayan grubun her ikisinin de özellikle objektiflik üzerinde durdukları ortaya çıkmıştır. Sluijsmans ve Moerkerke (1999) yaptıkları çalışmada, öğrencilerin değerlendirme kriterlerini arkadaşlık düzeyine göre belirlediklerini, akran değerlendirmeleri sırasında yumuşaklık, arkadaşlık puanı, sertlik gibi puanlama hatalarının da ortaya çıktığını belirtmişlerdir. Bu sonuç elde ettiğimiz bulgularla paralellik göstermektedir. Burnett ve Cavaye (1980) ise, beşinci sınıf tıp öğrencileri ile yaptıkları çalışmalarında, akran değerlendirmelerindeki hatalardan birisi olan arkadaşlık puanlamasının büyük bir problem olarak görülmeyebileceğini belirtmişlerdir (Akt. Özan \& Yurdabakan, 2008). E3 kodlu öğretmen adayının “Akran değerlendirmesi yapılırken, ölçme değerlendirme işlemi sırasında yapılma ibtimali olan hata türlerinin etkisinin en az̧a indirilmesine, kişiye karşı objektif olunmaya, yapılan uyarları meşru bir düzene oturtulup kişilerin öz güven ve motivasyonlarmm kırlmamasina ve en önemlisi kişinin yaptığg hatalardan dolayı kü̧̈ük düsürülmemesine dikekat edilmelidir" ifadesiyle bu bulgunun çeliştiği görülmektedir.

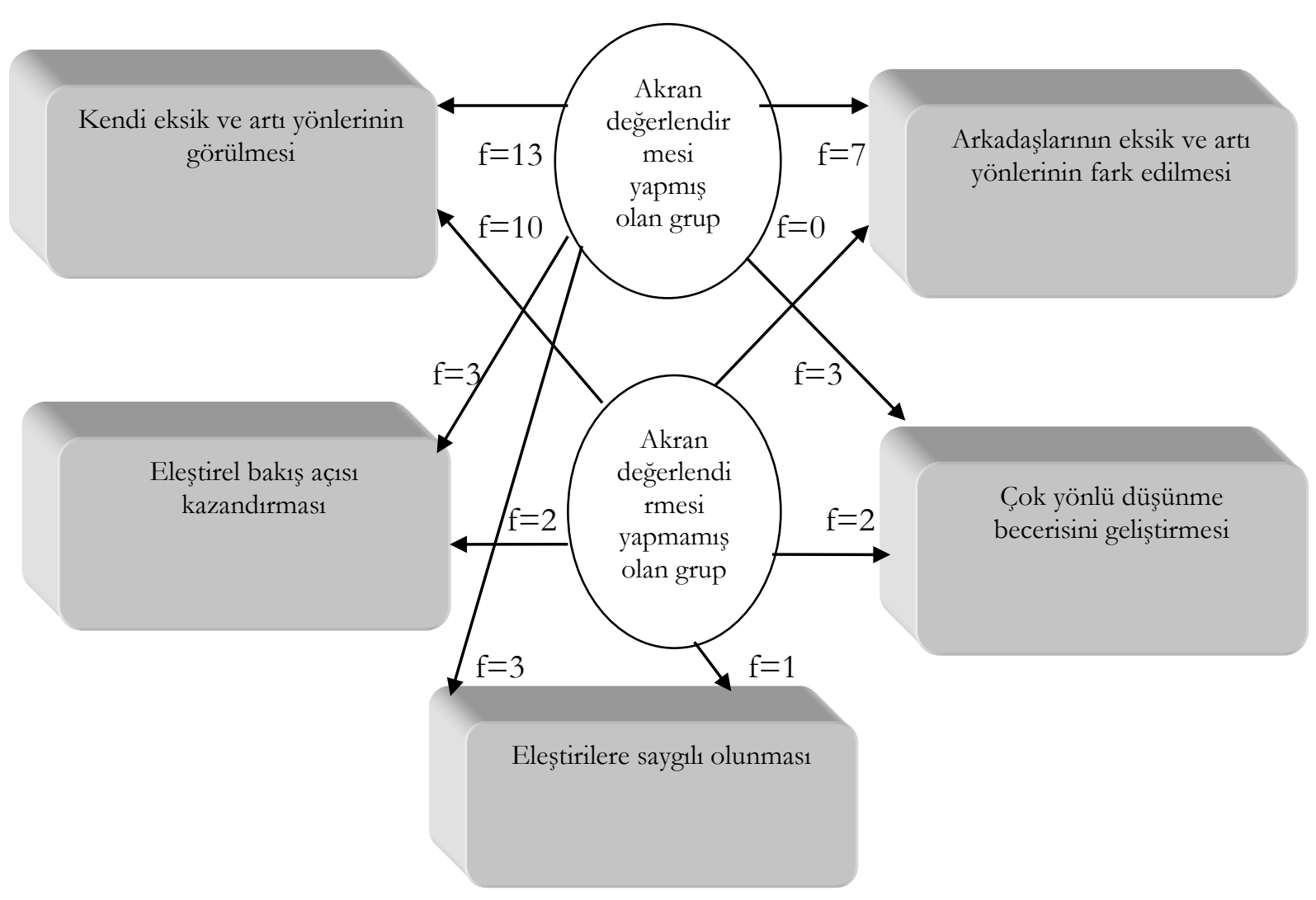

Şekil 3. Öğretmen adaylarının akran değerlendirmesinin olumlu yönlerine ilişkin görüşleri

Öğretmen adaylarının akran değerlendirmesine ilişkin olumlu gördüğü yönler yukarıdaki şekilde belirtilmeye çalışılmıştır. Yapılan anket sonucunda "kişinin eksik ve artı yönlerinin görülmesi” kategorisinin en yüksek frekansa ( $f=23$ ) sahip olduğu görülmüştür. Bu kategorinin, akran değerlendirmesi yapmış ve yapmamış olan iki grup tarafindan da en çok belirtildiği yapılan anket sonucunda belirlenmiştir. E3 kodlu öğretmen adayının bu konudaki görüşü “Akran değerlendirmesi sayesinde kişinin kendisini geliştirebileceğine, sağhlkh 
bir değerlendirme ile kendi yaşıtlarmmn kendisinin eksiklerinin söylenmesine karşıllk onlarn da hangi seviyelere ulastı̆ğ bakeknda bilgi edinilmesine imkan vereceğini düşünüyorum” şeklindedir. K9 kodlu öğretmen aday1 ise bu soruya "Birey değerlendirme sonrası kendi artı yönlerini kesfeder ve bunun yan sira farkında olmadĭg eksikleri görüp düzeltme yoluna gidebilir" şeklinde cevap vermiştir. K7 kodlu öğretmen aday1 da bu konuda "Bana göre akran değerlendirmesi bireyin öz farkındaliğmn kazanması açsından önemli bir detaydır. Kişinin kendini görmesi, tamması, eksike ya da art yönlerini bilmesi açısından çok önemlidir ’şeklinde görüş bildirmiştir. Öğretmen adayları, akran değerlendirmesinin hem kendilerini hem de akranlarını farklı açılardan görüp değerlendirebilme imkanını sağladığını, eleştirel bir bakış açısı kazandıklarını belirtmişlerdir. E15 kodlu öğretmen adayı "Öğrenciler değerlendirdiği arkadaşında gördï̆̈̈̈ olumlu ve olumsuz, seylere dikkat ederler ve kendileri de ona göre yapip yapmamaya karar verirler" şeklindeki ifadesiyle arkadaşlarının eksik ve artı yönlerinin fark edilip ona göre değişikliklere gidildiğini belirtmiştir. K13 kodlu öğretmen adayı bu durumu "Eleştirel bir bakış açısı getirdiğini düş̈̈nïyorum. Bu da insann eksiklerini görmesi adına ve ilerlemesi adına katke sağlayacaktır. Gözlem yeteneğini gelistirir. Bir durum bakkenda yorum yapabilme becerisini gelistirir. Hem bize bem de değerlendirmede bulunduğumuz akranımıza olumlu yönde katke sağlar." şeklinde ifade etmiştir. E27 kodlu öğretmen adayı ise soruya "Akran değerlendirmesi, değerlendirmeyi yapan kişiye birtakum beceriler kazandrrr. Gö̌lem, aynt edebilme ve mubakeme bu beceriler arasindadr. Cevreyi ve insanlar daha iyi çözümlemesine ve her yönüyle tanmasina yardımcı olur. Değerlendirilen kişsiye ise kendini başkasmm gözünde görme firsat verir. Eleștiri yeteneği kazandirdiğ gibi eleștiriye, olumsuz sonuclara tahammül etmeyi yani saygı göstermeyi ögretir ’ şeklinde cevap vermiştir. 'Çok yönlü düşünme becerisini geliştirme' kategorisine K12 kodlu öğretmen adayının verdiği cevap “Akran değerlendirmesi elesstirel beceri kazandiryor, empati yeteneğini gelistiriyor. Bu da ögrencide çok yönlü düşünme becerisinin geliştirilmesine katkı sağhlyor" şeklindedir. Bunun dişında verilerin analizi sonucunda öğretmen adaylarının akran değerlendirmesine ilişkin olumlu gördüğü yönler arasında "meslek hayatına hazırlama" kategorisinin en düşük frekansa $(\mathrm{f}=1)$ sahip olduğu ortaya çıkmıştır. K21 kodlu öğretmen adayı "Meslek hayatına hažrlaması açısından iyi oluyor. Kişinin kendini görmesine yardıma olmaktadır. Akranlar arasindaki iletişimi kolaylaștrmaktadır" şeklindeki ifadesiyle bu durumu belirtmiştir.

Öğretmen adayları akran değerlendirmesinin olumlu yönleri olarak, akranlarının ve kendilerinin eksik ve artı yönlerini görerek eksiklerini düzeltme imkanı bulduklarını belirtmişlerdir. Ayrıca, akran değerlendirme sürecinde akranlarının uygulamalarına daha eleştirel baktıklarını, uygulamalardaki olumlu ve olumsuz yönleri görmeye çalışırken eleştirel düşünme becerilerinin de geliştiğini belirtmişlerdir. Nitekim yapılan birçok araştırmada akran değerlendirmesinin eleştirel düşünmeyi, işbirliği becerilerini ve etkileşimi geliştirdiği, kendini ifade etme becerileri, eleştirme ve eleştirilere açı olma gibi pek çok becerilerinin gelişmesine de katkı sağladığı, öğrenme potansiyelini arttırdığı, öğretmenlik yeterliliklerini geliştirdiği yönünde bulgulara ulaşılmıştır (Topping, 2009; Willey \& Gardner, 2010; Koç, 2011; Başkonuş \& Taşdemir, 2012). Kurt ve Atay'ın (2007) yapmış olduğu çalışmada akran değerlendirmesinin İngilizce öğretmen adaylarının yazma kaygısı üzerine etkisi araştırılmıştır. Akran değerlendirme uygulanan deney grubunun öğretmen değerlendirmesi uygulanan kontrol grubuna göre daha düşük yazma kaygisına sahip olduğu tespit edilmiştir. Buna ek olarak öğretmen adayları akran değerlendirmesi uygulamaları sonucunda yazılarındaki hatalarının farkına vardıklarını, yazıları için arkadaşlarının farklı fikirler verdiklerini ve kendi yazılarına başka bir boyuttan bakabilmeye başladıklarını söylemişlerdir. İngilizce yazılı anlatım derslerinde akran değerlendirme ve öz değerlendirmenin uygulandığı başka bir çalışma da Wei ve Chen (2003) 
tarafindan yapılmıştır. 90 yüksek lisans öğrencisi üzerinde yürütülen çalışmanın sonucunda, akran ve öz değerlendirme teknikleri kullanımının öğrencileri yazılarına eleştirel ve analitik bir gözle bakma açısından teşvik ettiği görülmüştür. Ayrıca çalışmada öğretmen ve öğrencilerin değerlendirmede yaşadıkları sorunlara ilişkin çözüm önerileri getirilmiştir. Sonuç olarak K13 kodlu öğretmen adayının yapmış olduğu "Eleştirel bir bakıls açıs getirdiğini düsünüyorum. Bu da insanın eksiklerini görmesi adına ve ilerlemesi adma katkr sağlayacaktrr. Gözlem yeteneğini geliștirir. Bir durum hakkinda yorum yapabilme becerisini geliştirir. Hem bize hem de değerlendirmede bulunduğumuz akranmmı̨a olumlu yönde katker sağlar." ş̧eklindeki açıklamadan elde edilen bulguların literetürdeki bu çalısmaların sonuçlarını kısmen desteklediği görülmektedir.

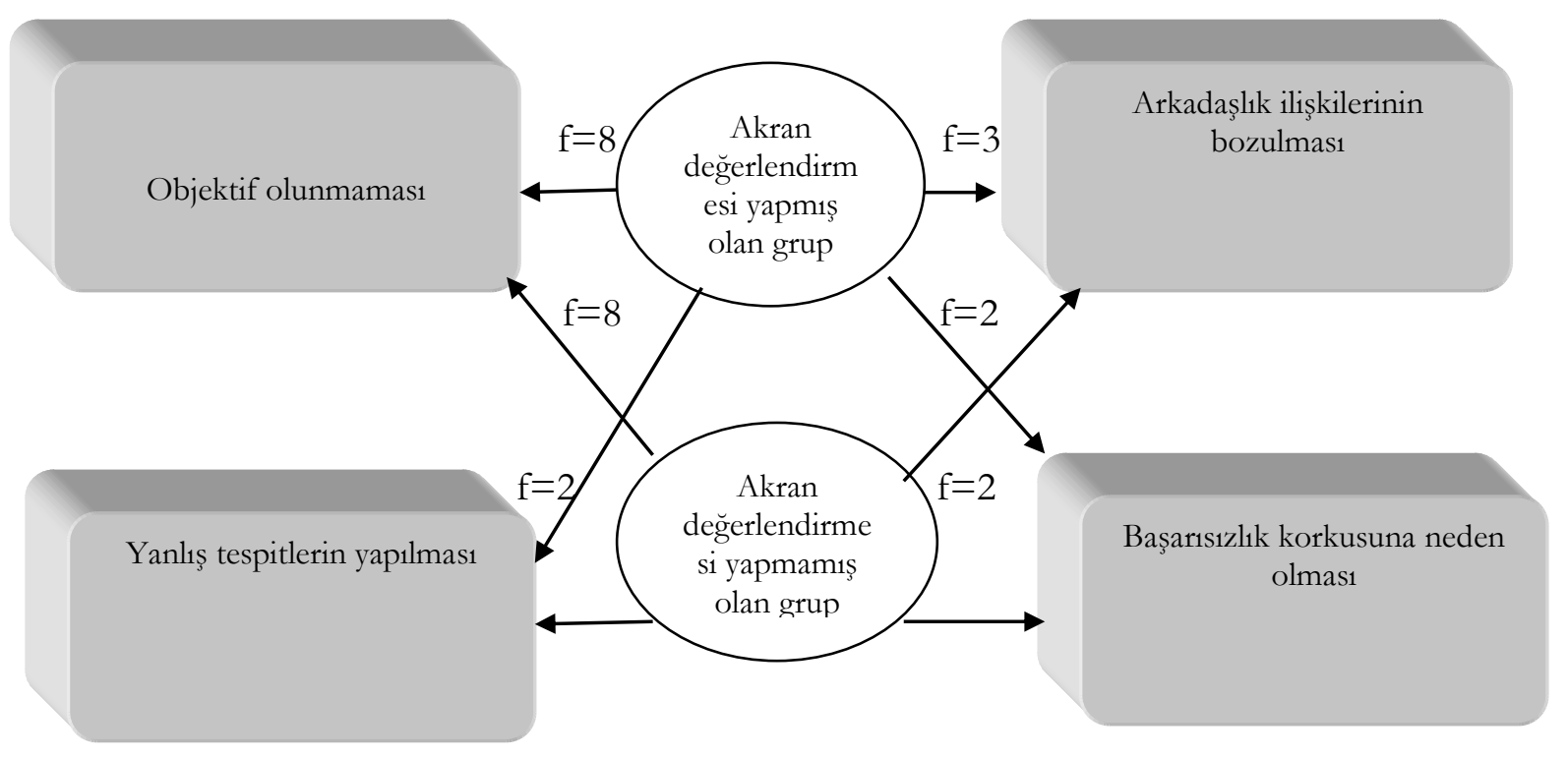

Şekil 4. Öğretmen adaylarının akran değerlendirmesinin olumsuz yönlerine ilişkin görüşleri

Şekil 4 incelendiğinde akran değerlendirmesinin olumsuz yönlerine ilişkin olarak 4 kategorinin ortaya çıktığı görülmektedir. Bunlar arasından objektif olunmaması görüşünün akran değerlendirmesinin öğretmen adayları tarafindan en fazla ifade edilen $(\mathrm{f}=16)$ olumsuz yönü olarak ortaya çıktığı belirlenmiştir. Akran değerlendirmesi yapmış $(\mathrm{f}=8)$ ve yapmamış $(\mathrm{f}=8$ ) olan iki grubun da akran değerlendirmesi yaparken bireylerin yanlı davranılabildiği konusunda görüş belirttikleri görülmektedir. K17 kodlu öğretmen adayı bu durumu "Kişisel özellikler, duygular ön plana çıkarsa gerçek görüsler ifade edilmeyebilir" şeklinde açıklamıştır. E28 kodlu öğretmen adayı ise, "Değerlendirmenin öznel bir tutumla yapılması değgerlendirmeye olumsuəluk katar" şeklinde görüş belirtmiştir. Öğretmen adaylarının olumsuz olarak gördüğü bir diğer yön de yapılan eleştirilerin arkadaşlık ilişkilerini bozduğudur. E3 bu durumu şöyle ifade etmiştir: "Kişi eleștirilmekten, yaşıtlarmm kendisi bakkemda fikir beyan etmesinden boșnt olmuyorsa o kişinin arkadaşlik iliskilerinde sıkıntı yaşayacağın düs̈̈̈nïyorum.” E28 kodlu öğretmen adayının 'yanlış tespitlerin yapılması' kategorisindeki görüşü ise "Değerlendirmeyi yapacak olan grubun akademik seviyesinin düşük olmast yanhs tespitleri de beraberinde getirebilir" şeklindedir. K13 kodlu öğretmen aday1 da bu durumu "Değerlendirme yaptığgmı k kişi sonuçta akranmmz olduğu için yamlmalar olabilir ya da aşıryy gidilebilir. Bu da olumsuz yönde etkileyecektir" şeklinde ifade etmiştir. 'Başarısızlık korkusuna neden olması' kategorisine yönelik K1 kodlu öğretmen adayının belirttiği görüş şu şekildedir: "Kişi eleştiriye ą̧ık değilse akran değerlendirmesi onu olumsuz etkileyebilir. Mesela isteksiz bir 
tutum takinmasina, başarısıそlhk korkusunun normalden fąla olmasina sebep olabilir". Bu soruya 3 kişi cevap vermezken, 1 kişide bir fikre sahip olmadığını belirtmiştir.

Öğretmen adayları, akranları tarafından objektif değerlendirme yapılmaması, arkadaşlarını değerlendirirken doğru değerlendirip değerlendirememe ve yapacakları değerlendirme sonucunda arkadaşlarının değerlendirmeye gösterecekleri tepkiler konusunda kaygı yaşadıklarını belirtmişlerdir. E25 kodlu öğretmen adayının bu konudaki görüşü " Akran değerlendirmesinin olumsuz olabilecek tek yanı eleştirdiğimiz, arkadasıımı̨n hatalarm kabul etmeyerek bize karşı bir tepkide bulunması olabilir" şeklindedir. K7 kodlu öğretmen aday1 ise "Birey eğer yetersiz̨liklerinin fąla olduğunu düs̈̈̈nürse bu onu güdülemek yerine psikolojik olarak incinmesine ve kendini yupratmasina neden olabilir. Birey içinde bulundü̆u durumu yanlıs anlayı farkh tepkiler gösterebilir" şeklinde bu durumu ifade etmiştir. Bostoc (2000)'a göre öğrenciler tarafindan yapılan değerlendirmenin güvenilirlik ve geçerliklerinin istenen düzeyde olup olmadığı, akran değerlendirmenin sakıncaları arasında yer almaktadır. Bu durumda süreç değerlendirme bağlamında öğrencilerden alınan geri bildirimin doğru ve etkili olup olmadı̆̆ı tartışlabilir. Çünkü öğrenciler tarafından yapılan akran değerlendirmeler hem öğrenmeyi hem de tek bir dersi etkileyebilecek bazı değişkenlere bağlıdır (Akt. Temizkan, 2009). Örneğin; akranlar arasındaki arkadaşlık ilişkileri öğrencilerin birbirlerine yüksek veya düşük puan vermelerine sebep olabilir. Çünkü öğrenciler kendi aralarında anlaşıp birbirlerine yüksek puan verebilirler. Bununla birlikte akranların öğretmen kadar bilgili ve bilinçli olmamaları da eksik ve yanlış değerlendirmelere yol açabilir. Dolayısıyla öğretmenler değerlendirme sürecini olumsuz etkileyebilecek bu tür olası durumları kontrol altında tutmalıdır (Temizkan, 2009).

Wheater, Langan ve Dunleavy (2005) yaptıkları araştırmada akran değerlendirme sürecine ilişkin problemleri belirlemeyi amaçlamışlardır. Bu amaç doğrultusunda hem süreç hem de ürün değerlendirme aşamasında akran değerlendirme tekniğini kullanmışlardır. Araştırmacılar akran değerlendirme sürecinde yaşanan en büyük problemin değerlendirmenin güvenirliliği konusunda olduğunu tespit etmiştir (Akt. Temizkan, 2009). Bu sonuç “Değerlendirmenin öznel bir tutumla yapılması değerlendirmeye olumsuə̨luk katar" (E28) bulgusunu kısmen destekler niteliktedir. Bir başka çalışma olan Gömleksiz ve Koç (2011)'un araştırmasında ise, akran değerlendirmenin olumsuz yönü olarak öğrenciler arasındaki yakın arkadaşlıklar nedeniyle kendilerinin değerlendirme yaparken duygusal ve yanlı davranabildikleri gösterilmiştir. Bu ifade bu araştırmada tespit edilen "Kişisel özellikler, duygular ön plana çlkarsa gerçek görïsler ifade edilmeyebilir" sonucunu destekler niteliktedir. 


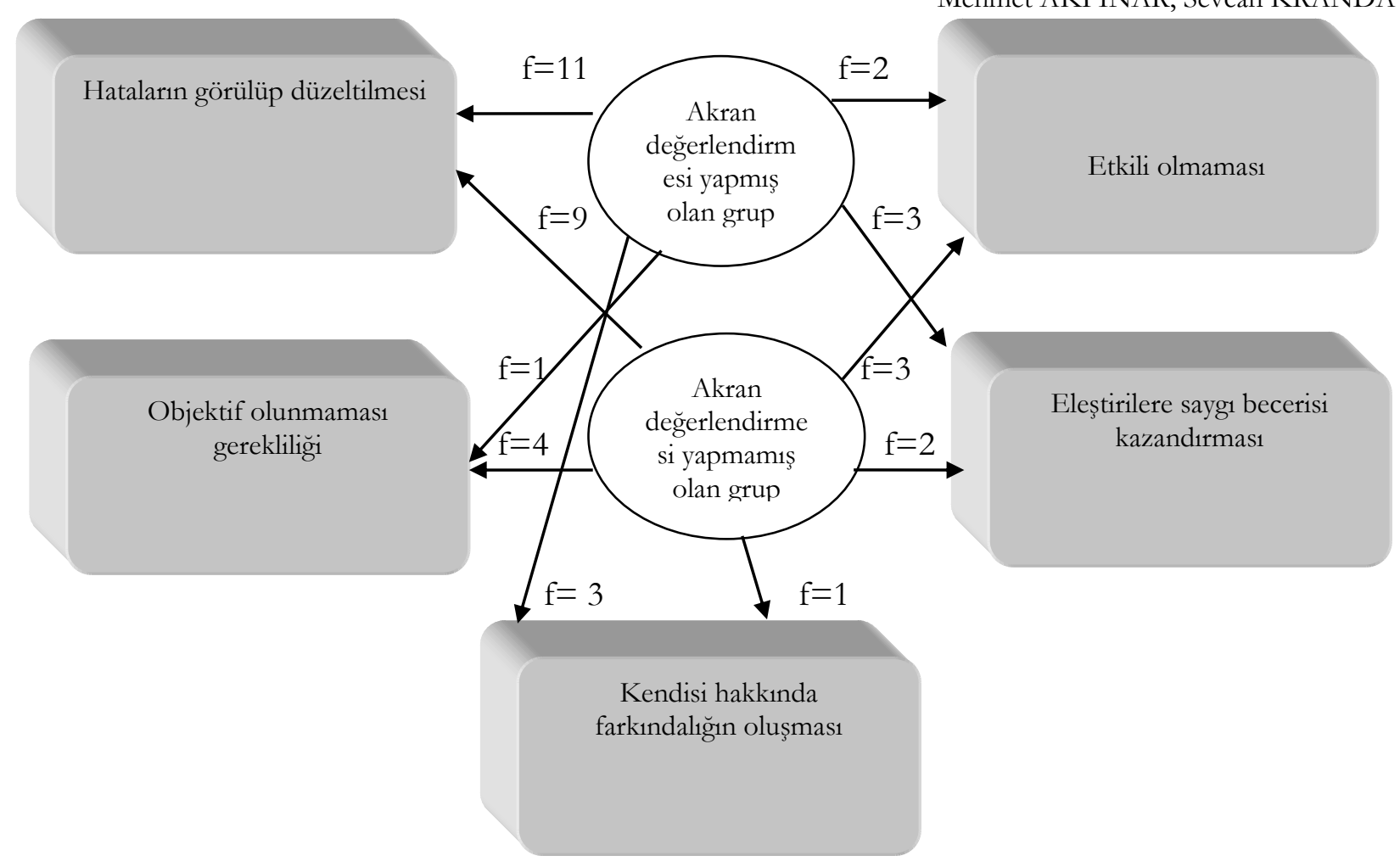

Şekil 5. Öğretmen adaylarının akranları tarafından değerlendirilme konusundaki görüşleri

Elde edilen bulgular sonucunda öğretmen adaylarının akranları tarafından değerlendirilmeleri konusundaki görüşleri ile ilgili olumlu ve olumsuz olmak üzere iki ana kategorinin ve bunların altında da çeşitli kategorilerin ortaya çıktığı görülmektedir. Olumlu görüşler kategorisinin altında "hataların görülüp düzeltilmesi”, "eleştirilere saygı becerisi kazandırması" ve "kendi hakkında farkındalığın oluşması” alt kategorileri toplanırken, olumsuz görüşler kategorisi altında "etkili olmaması" ve "objektif olunmaması" kategorileri yer almaktadır. Genel olarak değerlendirildiğinde öğretmen adaylarının çoğunun akranlanı tarafindan değerlendirilmeyi olumlu olarak gördüğü belirlenmiştir. E10 kodlu öğretmen adayı ise, genelde olumlu dönütler aldığı için bunu faydalı bulduğunu belirtmiştir. Öğretmen adayının bu konuda belirttiği görüş şu şekildedir: "Genelde olumlu sonuçlar aldığım ve eksiklerimi gördü̈üum için bana fayda sağlayan bir çalssmaydi". Olumlu görüşler kategorisindeki en yüksek frekansa $(\mathrm{f}=20)$ sahip olan görüş, akranları tarafindan değerlendirilen öğretmen adaylarının eksiklerini görüp bunları düzeltebilme imkanına sahip olmasıdır. Akran değerlendirmesi yapan ve yapmayan her iki grubun da en çok bu kategoride görüş bildirdiği şekil 5’te görülmektedir. K16 kodlu öğretmen aday1 "Yapılan değerlendirmeler eksiklerimi gidermemi, yanhşlarmı düzeltmemi ve iyi davramışlarmm pekiştirmemi sağhlyor" şeklinde bu soruya cevap vermiştir.

Yapılan anket sonucunda, akran değerlendirmesi hakkında hataların görülüp düzeltilmesi, eleştirilere saygı becerisi kazandırması ve kendi hakkında farkındalığın oluşması gibi olumlu görüşlerin yanı sıra akran değerlendirmesinin etkili bir ölçme aracı olmadığı ve objektif olunmadığı gibi olumsuz görüsslerin de olduğu ortaya çıkmıştır. Bu kategorilere öğretmen adaylarının benzer oranda ( $\mathrm{f}=5$ ) görüş belirttikleri yukarıdaki (Şekil 5) şekilde görülmektedir. Akran değerlendirmesinin etkili olmadığını belirten K8 ve K39 kodlu öğretmen adayları "Her zaman etkili olamayabilir" ifadesinde bulunmuşlardır. E14 kodlu öğretmen adayı ise "Daha çok duygularla bareket edip sevdiğimiz veya sorun yaşady̆ğmı insanlara karşı pek de tarafsız. olamadhğmı için değerlendirmeler sağhkh olmayabiliyor" şeklindeki ifadesiyle değerlendirirken objektif 
olunmadığına dikkat çekmiştir. Ö1 kodlu öğretmen adayı da "Herkesin bir fikri olduğuna ve fikirlerle varolduğumuza inanmıs biri olarak eleştiriye ve puanlamaya açı olmamı gerektiğini düs̈̈̈nüyorum. Bu da akranlarmıı̨n biə̧i değerlendirmesiyle sağlanabilir. Bu durumda yaptıklarm değerlendirilirse eleştiriye karşı olan antipatimi daha da az̧altarak hoşörïlï bir birey olabilirim" şeklindeki ifadesiyle akranlar tarafindan değerlendirilmenin eleștirilere karşı aç1k olmayı sağladığ1 görüşünü belirtmiştir. E25 kodlu öğretmen aday1 ise "Akranlarmmn beni değerlendirmesi benim için olumlu bir şeydir. Bu sayede hatalarmı anlayarak yapacağım şeyleri daha iyi bir şekilde yaparm. Aynca ayn seviyedeki arkadas grubu tarafindan değerlendirilmek kendimi daba iyi tanyabilmemi sağlayacaktr" şeklindeki cevabıyla kendisi hakkında farkındalığın oluştuğu görüşünü ortaya koymuştur. Bu soruya 4 ögretmen adayı ise cevap vermemiştir.

Akran değerlendirmesi ile öğrenenin öğrendikleri pekiştirilmekte ve birey kendi eksikliklerini belirleyerek daha nitelikli öğrenme yollarını aramaktadır (Topping, 1998). Çalışmamızdan elde edilen veriler de literatürdeki bu bulguları desteklemektedir. Öğrenciler akranlarının kendisini değerlendirmesinin olumlu yönleri arasında hatalarını görebilme fırsatını yakalamış olmalarını, arkadaşlarının bakışıyla kendilerini görmelerini, eleştirilere karşı saygılı olmayı sağladığını belirtmişlerdir.

Öğretmen adayları olumsuz olarak, akranlarının çok fazla objektif olamadıklarını ve bu yüzden değerlendirme sonuçlarının sağlıklı olmadığını belirtmişlerdir. Bundan dolayı öğretmen adayları objektif olunması gerekliliğini vurgulamışlardır. Bununla birlikte öğretmen adaylarının bazıları da akran değerlendirmesi uygulamasının her zaman etkili olmadığını ifade etmişlerdir. Akran değerlendirme üzerine yapılmış araştırmalarda, değerlendirme ölçütlerini arkadaşlık ilişkilerine göre belirleme, akranını değerlendirmeye kaygılı yaklaşma gibi bulgulara ulaşılmıştır (Sluijsmans \& Moerkerke, 1999; Koç, 2011). Kaufman ve Schunn (2008)'un 250 üniversite öğrencisi üzerinde gerçekleştirilen yazılı anlatımı değerlendirmede akran dönütlerinin etkililiğini sorguladıkları çalışmanın sonuçları ise, akran puanlamasıyla öğretmen puanlamasının birlikte yapıldığı durumlarda öğrencilerin akran değerlendirmesine ilişkin algılarının olumlu olduğunu ancak, yalnızca akrana bağlı kalınarak yapılan puanlamada algılarının düşük olduğunu ve birçok öğrencinin akran puanlamasını güvenilmez bulduğunu ortaya koymaktadır (Akt. Çetinkaya \& Hamzaday1, 2011). Bu ifade, çalışmamızdan elde edilen "Daha çok duygularla hareket edip

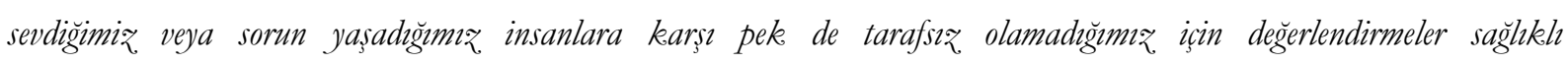
olmayabiliyor"'(E14) bulgusunu desteklemektedir. 


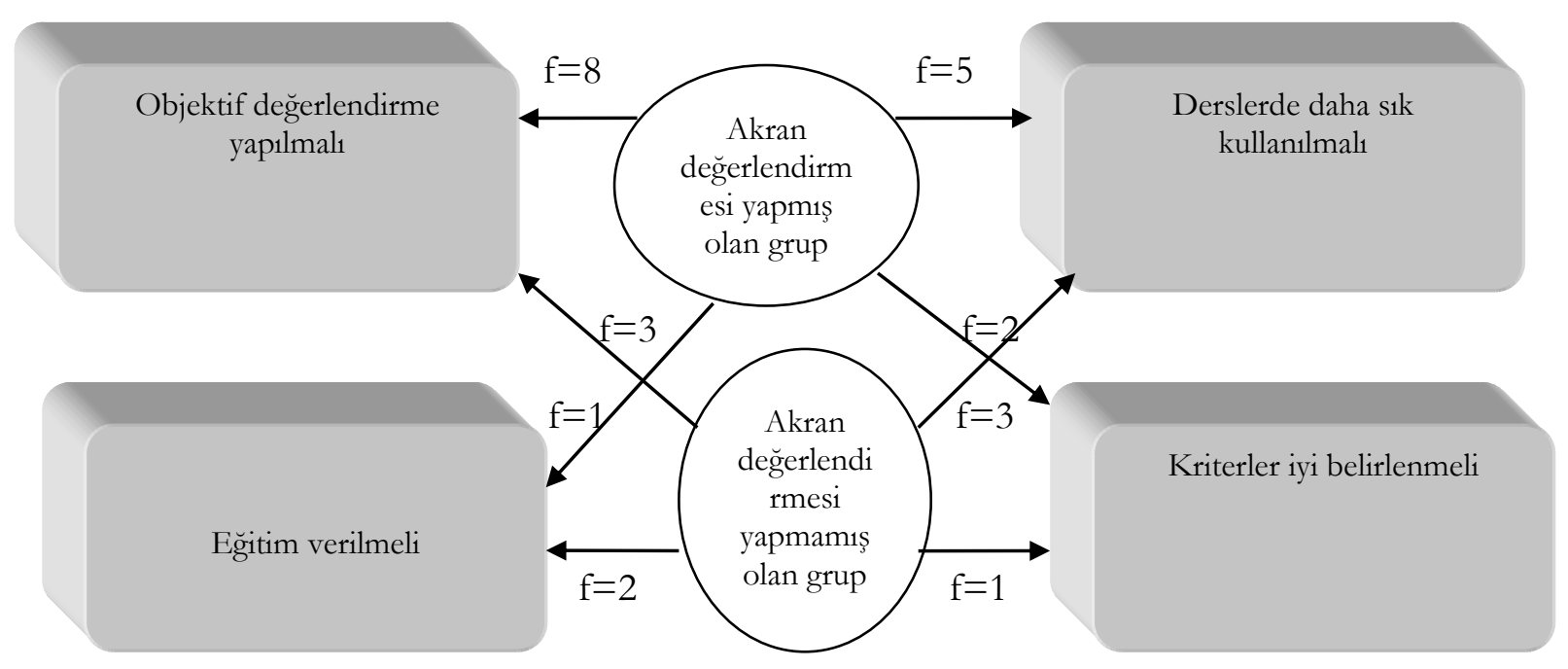

Şekil 6. Öğretmen adaylarının akran değerlendirmesine ilişkin önerileri

Şekil 6'da görüldüğü gibi öğretmen adaylarının akran değerlendirmesine ilişkin önerilerinde "objektif değerlendirme yapılmalı", "derslerde daha sik kullanılmalı", "kriterler iyi belirlenmeli” ve "eğitim verilmeli” şeklinde dört kategori ortaya çıkmıştır. Öğretmen adayları bunlar arasından en çok objektif olunması gerektiği üzerinde durmuşlardır. Anket sonucunda, akran değerlendirmesi yapan grubun ( $f=8)$ yapmamış olan gruba ( $\mathrm{f}=3$ ) göre objektif olunması gerektiği üzerinde daha çok durdukları görülmektedir. Bunun içinde akran değerlendirme formundaki kriterlerin dikkate alınması gerektiğinden bahsetmişlerdir. E4 kodlu öğretmen adayı "Akran değerlendirmesinde eksiklerin görülebilmesi için değerlendirme yapan bireyler objektif olmalddr" ifadesinde bulunmuştur. Diğer bir öneri ise, bu tekniğin derslerde daha sık kullanılması gerektiğidir. E28 kodlu öğretmen adayı "Değerlendirme yapacak olan grubun bu eğitimi almıs olması gerekir, aksi balde ciddi problemler yaşanabilir. Gerekli şartlar sağlandiğgnda çok verimli sonuclar elde edilebileceğinden ögrrenme-öğretme sürecinde fą̧laca kullanlmalıdır." şeklinde bu soruya cevap vermiştir. Yukarıdaki şekle bakıldığında, akran değerlendirmesi yapmış ve yapmamış olan iki grubun da 'eğitimin verilmesi' ve 'kriterlerin iyi belirlenmesi' gerektiği kategorilerine aynı frekansta ( $\mathrm{f}=3$ ) cevap verdikleri görülmektedir. K1 kodlu öğretmen adayının belirtmiş olduğu öneri “Akran değerlendirme eğitimi verilerek kişi nasıl değerlendireceğ̈ni öğrenmelidir. Saygzll olarak ve

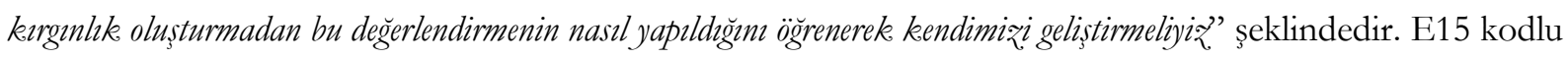
öğretmen adayı ise "Öğgrencilere tarafsız ve doğgru bir şekilde değerlendirme yapmalar konusunda bilgilendirme yapılmal. Değerlendirme kriterleri detaylh ve anlaşlle bir şekilde belirtilmell" ifadesiyle kriterlerin iyi belirlenmesi gerektiği konusunda öneride bulunduğu görülmüştür. Akran değerlendirmesine ilişkin 8 öğretmen adayı ise hiçbir öneride bulunmamıştır.

Öğretmen adayları, akranların objektif olabilmesinin sağlanabilmesi için akran değerlendirme etkinliklerinin sayısının artırlabileceğini, derslerde daha sık uygulanabileceğini vurgulamışlardır. Öğretmen adayları akranların birbirlerini yeterince nesnel değerlendiremediklerini belirtmişler ve bu yüzden objektif davranılması gerektiği önerisinde bulunmuşlardır. Öğretmen adayları, akran değerlendirmesinin daha etkili olması ve değerlendirme konusunda daha fazla şey öğrenmeleri için, akran değerlendirmesinin derslerde 
daha sı uygulanmasını önermişlerdir. Ayrıca bu değerlendirmeyi yapacak olan gruba akran değerlendirmesi ile ilgili eğitimin verilmesi önerisinde bulunmuşlardır.

\section{SONUÇ ve ÖNERİLER}

Bu çalışmada, öğretmen adaylarının akran değerlendirmesiyle ilgili görüşleri incelenmiş ve alt problemlere ilişkin aşağıdaki sonuçlara ulaşılmıştır.

1) Akran değerlendirmesi yapmış olan grupla yapmamış olan grubun akran değerlendirmesinin ne olduğuna ilişkin bilgi sahibi oldukları tespit edilmiştir. Öğretmen adayları akran değerlendirmesini, yaş ve statü bakımından benzer olan kişilerin birbirlerini değerlendirmesi ve akranın performansına bakılarak olumlu olumsuz yönlerinin söylenmesi şeklinde ifade etmişlerdir.

2) Akran değerlendirmesi uygulaması yapan öğretmen adayları ile yapmayan öğretmen adayları değerlendirme sırasında puanlama yapılırken daha çok objektif olmaya dikkat edilmesi gerektiğini belirtmişlerdir. Anlatılan konuya hakim olunması ve anlatış tarzına dikkat edilmesi gerektiği ise akran değerlendirmesi yapmış olan grubun belirttiği noktalar arasında yer almaktadır. Bu konuda, objektif olunması gerekliliğinin dışında iki grup arasında faklı görüşlerin ortaya çıktığı görülmüştür.

3) Çalışmada öğretmen adaylarının genel olarak akran değerlendirmesiyle ilgili olumlu algılara sahip oldukları saptanmıştır. Öğretmen adayları, akran değerlendirmenin kendi başarılı ve zayıf yönlerine ilişkin farkındalıklarını artırdığı görüşündedirler. Akran değerlendirmesi yapan grubun hem kendi hem de arkadaşlarının zayıf ve güçlü yönlerini gördüklerini belirtirken, akran değerlendirmesi yapmayan grubun sadece kendi zayıf ve güçlü yönlerini gördükleri ortaya çıkmıştır. Öğretmen adayları ayrıca, akran değerlendirmenin eleştirel düşünmeyi geliştirdiğini belirtmişlerdir. Akran değerlendirmenin eleştirel düşünme üzerindeki olumlu etkisi, akran değerlendirme sürecinde adaylarının belirlenmiş ölçütleri kullanarak akranlarının çalışma veya performanslarının eleştirisini yapmaları ile açıklanabilir. Öğretmen adayları akran değerlendirmenin kendilerini ileriki meslek yaşamlarında karşılaşacakları değerlendirilme süreçlerine de hazırladığı görüşündedirler.

4) Öğretmen adayları, akranları tarafından objektif değerlendirme yapılmamasını akran değerlendirmesinin en önemli olumsuzluğu olarak göstermişlerdir. Ayrıca, arkadaşlarını değerlendirirken doğru değerlendirip değerlendirememe ve yapacakları değerlendirme sonucunda arkadaşlarının değerlendirmeye gösterecekleri tepkiler konusunda endişe yaşadıklarını belirtmişlerdir. Yapılan çalışma sonucunda akran değerlendirmesinin olumsuz yönlerine ilişkin akran değerlendirmesi uygulaması yapan grupla yapmayan grup arasında anlamlı bir farkın olmadığ görülmüştür.

5) Öğretmen adaylarının, akranlarının kendilerini değerlendirmesini daha çok olumlu olarak karşıladıkları görülmektedir. Öğrenciler akranlarının kendisini değerlendirmesinin olumlu yönleri arasında hatalarını görebilme fırsatını yakalamış olmalarını, arkadaşlarının bakışılla kendilerini görmelerini, eleştirilere karşı saygılı olmayı sağladığını ifade etmişlerdir. Öğretmen adaylarının bir kısmı ise, akranları tarafindan değerlendirilmenin olumsuz yönleri üzerinde durdukları görülmüştür. Akranlarının çok fazla objektif olamadıklarını ve bu yüzden değerlendirme 
sonuçlarının sağlıklı olmadığını belirtmişlerdir. Gruplar araştırma sürecinde daha çok objektif olunması gerekliliğini vurgulamışlardır. İki farklı grubun da aynı noktalar üzerinde durduğu görüldügünden dolayı gruplar arasında anlamlı bir farklılık olmadığı tespit edilmiştir.

6) Çalışma bazında yapılan karşılaştırmalar akran değerlendirmesi yapan grubun diğer gruba oranla akran değerlendirmeye ilişkin görüşlerinin daha olumlu olduğunu göstermişstir. Akran değerlendirmesi yapan grubun daha deneyimli olması bunun önemli nedenleri arasında gösterilebilir.

Bu çalışmada ulaşılan bulgular çerçevesinde şu öneriler sunulabilir:

1) Alanyazın incelendiğinde, akran değerlendirmesi ile ilgili öğrencilerin görüşlerini belirleyen çalışmaların sınırlı sayıda olduğu görülmektedir. Bu sebeple bu alanla ilgili daha çok araştırma yapılmalıdır. Yapılacak olan çalışmalarla öğrencilerin akran değerlendirmesi ile ilgili görüş ve eksiklikleri belirlenmeli ve bunlar tespit edildikten sonra öğrencilerin eksiklerinin giderilmesi için öğrenciler akran değerlendirme konusunda bilgilendirilmelidir.

2) Öğretmen adayları, akran değerlendirmesi yapılırken öznel yargılara yer verildiğini belirtmişlerdir. $\mathrm{Bu}$ nedenle, ölçme-değerlendirmeyi konu alan derslerde akran değerlendirmesinin önemi ve kullanımına daha fazla yer verilmelidir. Öğretim elemanlarının da akran değerlendirmesi gibi performansa dönük yöntemleri derslerinde kullanarak öğretmen adaylarına örnek olması gerekmektedir.

3) Çalışmada, öğretmen adaylarının objektif olmaması en önemli olumsuzluk olarak ifade edilmiştir. Akran değerlendirmesi yapacak olan kişilerin arkadaşlık ilişkilerine göre yanlı davranmalarını engellemek için puanlama kriterlerine göre değerlendirme yapma alıskanlığını kazanmış olmaları gerekmektedir. $\mathrm{Bu}$ da akran değerlendirmesi tekniğinin derslerde daha sık kullanılmasıyla sağlanabilir.

4) $\mathrm{Bu}$ araştırma sosyal bilgiler öğretmen adayları üzerinde yapılmıştır. Diğer alanlardaki öğretmen adayları üzerinde de akran değerlendirmesi ile ilgili çalışmalar yürütülerek karşılaştırılabilir.

5) Bireyler akranlarını nasıl değerlendirecekleri konusunda bilgilendirilmeli, akran değerlendirmede yer alacak kriterler akran değerlendirmesi yapacak olanların da görüşü alınarak belirlenmelidir. Ayrıca doğru bir planlama yapılarak akran değerlendirmesi uygulanmalıdır.

6) Öğrencilere, akran değerlendirmesi sürecinde yapılan eleştirilerin geri bildirim alan öğrenciye faydalı olacağı ve akranlarının performanslarını veya çalışmalarını eleştirmekten çekinmemeleri belirtilmelidir.

Bu çalışmada öğretmen adaylarının akran değerlendirmesine ilişkin görüşleri ele alınmıştır. Sonraki çalışmalarda, akran değerlendirmesi becerilerinin geliştirilmesine yönelik yapılacak olan uygulamaların sosyal bilgiler eğitiminde önemli bir boşluğu dolduracağına inanılmaktadır.

\section{KAYNAKÇA}

Adanalı, K. \& Doğanay, A. (2010). Beşinci sınıf sosyal bilgiler öğretiminin alternatif ölçme değerlendirme etkinlikleri açısından değerlendirilmesi. C..Ü. Sosyal Bilimler Enstitïsü Dergisi, 19(1), 271-292. 
Akbaş, Y. \& Gençtürk, E. (2013). Coğrafya öğretmenlerinin alternatif ölçme-değerlendirme teknikleri ile ilgili görüşleri: Kullanma düzeyleri, sorunlar ve sınırlilıklar. Doğı Coğrafja Dergisi, 30, 331-356.

Aldağ, H. \& Gürpınar, K. (2007). Üniversite öğrencilerinin sunu becerilerini etkileyen faktörler. Akademik Bilisim Konferansı, 31 Ocak - 2 Şubat 2007, Kütahya.

Alıcı, D. (2008). Öğrenci performansının değerlendirilmesinde kullanılan diğer ölçme araç ve yöntemleri. S. Tekindal (Ed), Eğitimde Ölçe ve Değerlendirme. Ankara: Pegem Akademi.

Atay, D. \& Kurt, G. (2007). The effects of peer feedback on the writing anxiety of prospective Turkish teachers of EFL. Eg̈itimde Kuram ve Uygulama( Journal of theory and Practice in education). 3(1), 12-23.

Baki, A. (2008). Kuramdan uygulamaya matematike eğitimi. (Genişletilmiş 4. Basım). Ankara: Harf Eğitim Yayıncilı̆̆ı.

Başkonuş, T. \& Taşdemir, M. (2012). İlköğretim birinci kademe sosyal bilgiler programında (4. ve 5. sınıf) yer alan alternatif ölçme değerlendirme araç ve yöntemlerinin kullanılma ve kullanılmama durumları. 11. Ulusal Simif Öğretmenliği Ë̆itimi Semposyumu, 24-26 Mayss, Rize.

Bayat, Ö. (2010). İngilizce yazılı anlatım derslerinde uygulanan akran ve öz değerlendirme etkinliklerine yönelik öğrenci görüşleri. Dil Dergisi, 150 (20).

Büyüköztürk, Ş. (2001). Deneysel deneyler, ön test-son test, kontrol grubu desen ve veri analizi. Ankara: Pegem A Yayıncilik.

Chong, M., R., Goff, L. \& Dej, K.(2012). Undergraduate essay writing: online and face-to-face peer reviews. Collected Essays on Learning and Teaching, 5, McMaster University.

Cihanoğlu, M.,O. \& Yurdabakan, İ. (2009). Öz ve akran değerlendirmenin uygulandığ işbirlikli okuma ve kompozisyon tekniğinin başarı, tutum ve strateji kullanım düzeylerine etkisi. Dokuz. Eylül Üniversitesi Sosyal Bilimler Enstitüsï Dergisi, 11(4), 105-123.

Çelikkaya, T., Karakuş, U. \& Demirbaş, Ç., (2010). Sosyal bilgiler öğretmenlerinin ölçme değerlendirme araçlarının kullanma düzeyleri ve karşılaştıkları sorunlar. Abi Evran Üniversitesi Dergisi, 11(1), 57-76.

Çepni, S. (2007). Performansların değerlendirilmesi. E. Karip (Ed.), Ölçme ve Değerlendirme, Ankara: Pegem A Yayincilik.

Çepni, S. (2009). Arastırma ve proje çallsmalarna giriş. Trabzon: Celepler Matbaacilık

Çetinkaya, G. \& Hamzadayı, E. (2011). Yazılı anlatımı düzenlemede akran dönütleri: Dönüt türleri, öğrenci algilar1. AİB̈̈, Eg̈itim Fakültesi Dergisi, 11(1), 147-165.

Çoruhlu, Ş., Nas, S. \& Çepni, S. (2009). Fen ve teknoloji öğretmenlerinin alternatif ölçme değerlendirme tekniklerini kullanmada karşılaştıklar1 problemler: Trabzon örneği. Yüzüncü Yul Üniversitesi, Eğitim Fakültesi Dergisi, 6(1), 122-141.

Ekiz, D. (2009). Bilimsel araştırma yöntemleri (Geliştirilmişs 2. Baskı), Ankara: Anı Yayıncllık.

Falchikov, N. (2001). Learning together: Peer tutoring in higher education. London: Routledge.

Gelbal, S. \& Kelecioğlu, H. (2007). Öğretmenlerin ölçme ve değerlendirme yöntemleri hakkındaki yeterlik alg1ları ve karşılaştıkları sorunlar. Hacettepe Üniversitesi Eğitim Fakültesi Dergisi ( H. U. Journal Of Education), 33, 135-145.

Gömleksiz, M. A. \& Koç, A. (2011). Bilgisayar kullanımı ögretiminde akran değerlendirme. 5th International Computer \& Instructional Technologies Symposium. Firat University, Elazığ- Turkey.

Güven, S. (2008). Sınıf öğretmenlerinin yeni ilköğretim ders programlarının uygulanmasına ilişkin görüşleri, Milli Ë̆itim Dergisi, 177, 224-236.

Koç, C. (2011). Sınıf öğretmeni adaylarının öğretmenlik uygulamasında akran değerlendirmeye ilişkin görüssleri. Kuram ve Uygulamada Eğitim Bilimleri, 11(4), 1965-1989.

Liu, N. F. \& Carless, D. (2006). Peer feedback: The learning element of peer assessment. Teaching in Higher Education, 11(3), 279-290.

Özan, S. \& Yurdabakan, İ. (2008). Öz ve akran değerlendirmenin temel iletişim becerileri başarısı üzerindeki etkileri. T⿰力 Ë̆itim Dünyası, 27, 27-39. 
Özcan, G. \& Mirzeoğlu, A., D. (2015). Akran öğretimiyle işlenen okul deneyimi dersi hakkında öğrenci görüşleri ve kazanımları. Sport Sciences (NWSASPS), 10(4), 16-33.

Sluijsmans, D., \& Moerkerke, G.( 1999). Student involvement in performance assessment: A research project.

Sluijsmans, D., \& Prins, F. (2006). A theoretıcal framework for integratıng peer assessment in teacher education. Studies in Educational Evaluation, 32, 6-22.

Temizkan, M. (2009). Akran değerlendirmenin konuşma becerisinin geliştirilmesi üzerindeki etkisi. Mustafa Kemal Üniversitesi Sosyal Bilimler Enstitüsü Dergisi, 6(12), 90-112.

Topping, K. (1998). Peer assessment between students in colleges and universities. Revien of Educational Research, 68, 249-276.

Topping, K. J. (2009). Peer assessment. Theory into Practice, 48, 20-27.

Toptaş, V. (2011). Sınıf öğretmenlerinin matematik dersinde alternatif ölçme ve değerlendirme yöntemlerinin kullanımı ile ilgili alg1ları. Ë̆itim ve Bilim, 36(159), 205-219.

Wei, Y., \& Chen, Y. (2004). Supporting Chinese learners of english to implement self-assessment in L2 writing. Proceedings of the Independent Learning Conference, 20 September 2004.

Willey, K., \& Gardner, A. (2010). Investigating the capacity of self and peer assessment activities to engage students and promote learning. European Journal of Engineering Education, 35(4), 429-443.

Yıldırım, A. \& Şimşek, H. (2011). Sosyal bilimlerde nitel araştırma yöntemleri (8. Baskı). Ankara: Seçkin Yayınevi.

\section{Citation Information}

Akpınar, M. \& Kranda, S. (2016) Sosyal Bilgiler Öğretmen Adaylarının Akran Değerlendirmesine İlişkin Görüşleri. Dicle Üniversitesi Ziya Gökealp Ë̆itim Fakültesi Dergisi, 29, 356-374. 